\title{
Herbivory effects and growth rate of invasive species, Pomacea canaliculata on different macrophytes species
}

\author{
Hasnun Nita Ismail ${ }^{1,{ }^{*}}$, Wan Nurul Hidayah Wan Anuar ${ }^{1}$, Noormawaty Mohammad Noor ${ }^{2}$ \\ ${ }^{1}$ Department of Biology, Faculty of Applied Science, University Technology of MARA, Perak Branch, Tapah Campus, 35400 Tapah Road, Malaysia \\ ${ }^{2}$ Kuliyyah of Science, International Islamic University, Jalan Sultan Ahmad Shah, Bandar Indera Mahkota, 25200 Kuantan, Pahang, Malaysia
}

\begin{abstract}
Wetland ecosystems act as natural freshwater purification systems, but their rich biodiversity is being threatened with the introduction of the non-native freshwater snail, Pomacea canaliculata. This study was conducted to measure the herbivory effects and growth rate of $P$. canaliculata on common macrophytes: Ipomoea aquatica, Ipomoea batatas, Pandanus amaryllifolius and Cucurma longa. In separate experiments, the macrophyte species were served as the snails' food as individual species and simultaneously. In the individual treatment, the growth pattern and rate were based on the snails' weight ( $\mathrm{mg} / \mathrm{snail} /$ day; $\mathrm{n}=9$ ) while the individual feeding consumption ( $\mathrm{mg} / \mathrm{snail} / \mathrm{day}$ ) was calculated from the leftover food. In the simultaneous treatment, the herbivory effects were evaluated as the feeding preference (\%) from observations every two hours, while the total feeding consumption $(\mathrm{mg})$ was calculated based on the food remaining after a 12-hour experiment (3 replicates: total $\mathrm{n}=27$ ). The results indicated that the growth pattern was significant for snails grazing on l. aquatica but not when other macrophyte species were eaten. The individual feeding consumption was higher when using I. aquatica than $P$. amaryllifolius but the growth rate for snails grazing on I. aquatica and P. amaryllifolius did not differ significantly. Meanwhile, the consumption of $C$. longa deterred the snails' growth rate. Although the snails consumed all the macrophytes in the individual experiment, when given the species simultaneously, the feeding preference and total feeding consumption were directed significantly more toward I. aquatica than $P$. amaryfollius and $C$. longa. We conclude that $P$. canaliculata is a generalist feeder given a limited choice of food but tends to show a strong feeding preference after being introduced to more food choices. These findings indicate that the introduction of $P$. canaliculata into wetland ecosystems may increase the herbivory effects on macrophytes, making these ecosystems vulnerable to the impact of eutrophication and biodiversity reduction.
\end{abstract}

Keywords: Golden apple snail, Invasive, Growth rate, Feeding consumption, Macrophytes

\section{Introduction}

Wetland ecosystems are highly valuable natural assets. They provide clean water, flood control, pollution retention, groundwater recharge, nutrient sources, and habitats for many species of flora and fauna (Clarkson et al., 2013). In some countries,

\footnotetext{
Received: Aug 29, 2021 Revised: Nov 2, 2021 Accepted: Nov 8, 2021

${ }^{\star}$ Corresponding author: Hasnun Nita Ismail

Department of Biology, Faculty of Applied Science, University Technology of MARA, Perak Branch, Tapah Campus, 35400 Tapah Road, Malaysia Tel: +60-5-406-7331, Fax: +60-5-406-7712, E-mail: hasnunnita@uitm.edu.my

This is an Open Access article distributed under the terms of the Creative Commons Attribution Non-Commercial License (http://creativecommons.org/licenses/by$\mathrm{nc} / 4.0 /$ ) which permits unrestricted non-commercial use, distribution, and reproduction in any medium, provided the original work is properly cited.

Copyright $\odot 2021$ The Korean Society of Fisheries and Aquatic Science
} 
these ecosystems generate economic income through activities such as tourism, aquaculture, and recreation (Ghermandi et al., 2008). However, the exploitation of wetlands through economic activities has caused these ecosystems to disappear at an alarming rate. Uncontrolled land conversion and industrial development exploited these ecosystems until the authorised government enforced wetland laws and regulations for their protection and restoration (Gibbs, 2000). Legal enforcement seems to have been effective in reducing human exploitation. Nevertheless, wetlands continue to be vulnerable due to issues related to the introduction of new species.

It is well documented that most introduced species eventually become invasive in wetland ecosystems (Zedler \& Kercher, 2004). An invasive species is defined as an introduced species that has spread rapidly in a new region (Ricciardi \& Cohen, 2007). When new species are introduced, the full impact is generally unpredictable. Eventually, the introduced species develop into invasive species (Simberloff, 2010). They damage the ecosystem through herbivory habits and potentially replace the native herbivorous species (Tu et al., 2018), while they also exploit niches and habitats, eventually altering the ecosystem's structure and function (Whitney \& Gabler, 2008). Some invasive species have far-reaching repercussions on humans as they damage agricultural crops and act as vectors to some human parasites (Yang et al., 2013). In addition, the absence of natural predators in the ecosystem to which they are introduced enhances the sustainability of the invasive species.

One significant invasive species in wetland ecosystems is the golden apple snail, Pomacea canaliculata, which originates from South America (de Brito \& Joshi, 2016). The golden apple snail is a freshwater snail that has dominated wetland ecosystems in South East Asian countries since its first introduction. They can be found around natural wetlands, rivers, lakes, ditches, and in man-made agricultural areas. Their first introduction, in the 1980s, was intended to be as a high-protein food source in Taiwan (Naylor, 1996). Snail-farming activities were expected to offer alternative sources of income to local people. Meanwhile, the snail spread to Vietnam, China, Japan, Korea, Indonesia, Thailand, and the Philippines. However, its introduction was unsuccessful because the locals disliked the taste of the snail. As a result, the snail populations were abandoned and carelessly dumped into the local environments. In our country, Malaysia, the population was first spotted in 1991, as reviewed by Yahaya et al. (2017). It is unknown how they were brought to Malaysia because the Malaysian Government has never encour- aged either snail farming or snail commercialization. However, it is believed that the snail was imported by aquarium traders and in vegetables imported from Thailand (Yahaya et al., 2017). Within ten years of its first appearance, the population had been classified as a national quarantine pest due to the major damage it caused in agricultural areas.

The South East Asian countries and the original region of South America are similar in terms of climatic conditions. The snail ideally proliferates in a climate in which dry and wet seasons are typical. Undeniably, the wetland ecosystems in South East Asia have long been rich in diversity and high in vegetation density. They contain a wide range of vegetation, starting from the high, intermediate, and low canopies, and including macrophytes. Macrophytes are aquatic plants that grow in or near water and are either emergent, submergent, or floating (Ahmad et al., 2019). These plants mostly are characterized by their soft, succulent body parts which make them the main food source for the golden apple snail. In previous literature, a golden apple snail population has been reported to cause a negative impact on macrophytes in wetland ecosystems (Carlsson \& Lacoursière, 2005; Fang et al., 2010) and serious damage to wetland agriculture areas has been observed due to their herbivory effects (Joshi \& Sebastian, 2006). The worst scenario was observed in Thailand when aquatic plants completely disappeared from 14 wetland ecosystems, which consequently reduced the water quality due to the nutrient increments and frequent algal blooming (Carlsson et al., 2004). Herbivory and heavy grazing pressure have been widely reported where the preferable macrophytes include semi-aquatic plants such as water hyacinth, water spinach, water cabbage, duckweed, lotus, water chestnut, taro, and paddy plants (Ip \& Qiu, 2017).

Generally, the wetland ecosystems in South East Asian countries provide a wide range of food sources that support the proliferation of the golden apple snail. However, the snail's herbivory and grazing ability may depend on the type of plant species. It is unknown whether the snail has the ability of food selection, but some studies have reported evidence of its food preference (Cruz et al., 2015; Gilal et al., 2016; Morrison \& Hay, 2011; Pradabphetrat et al., 2018). Food preference depends largely on the plant's physical characteristics and secondary metabolites. Physical characteristics such as spines, thick cellulose, and numerous leaf veins reportedly deter the grazing process (Wong et al., 2010). Meanwhile, secondary metabolites (phenolics, alkaloids, terpenes, and wax) are probably toxic or interfere with the plant's palatability and its digestion as a 
food (Lodge, 1991; Qiu \& Kwong, 2009). However, other studies have demonstrated that the presence of phenolic does not significantly affect the feeding rate (Wong et al., 2010) and the presence of sharp feeding organs, radula, increases the herbivory on plants with various physical characteristics. Therefore, this study aims to evaluate the herbivory effects and growth rate of juveniles of $P$. canaliculata on several macrophyte species commonly found in local wetland ecosystems. Snails at the juvenile stage were selected for the experiment because at this life stage, the snail's physiology is driven by the need to feed and grow, without much interference from activities related to reproduction and mating. The herbivory effects were translated based on their feeding consumption and feeding preference for macrophyte species. The findings may provide an understanding of the biological invasion of $P$. canaliculata and their potential domination of either wetland ecosystems or agricultural areas if they evolve and adapt to their new environmental conditions.

\section{Materials and Methods}

\section{Sample collection of $\boldsymbol{P}$. canaliculata at the juvenile stage}

In this study, the species were collected from a wild population in a public waterway in front of the main campus at Tapah Road, Perak. The identification of the species was determined from the description provided by Arfan et al. (2014). P. canaliculata at the juvenile stage were selected, so their shell lengths were between 10 and $18 \mathrm{~mm}$, as classified by Gamarra-Luques et al. (2013). The shell length diameter measurement was determined using a Vernier caliper. All the selected juveniles were kept in a container and transported to the Plant Laboratory of the University Technology of MARA, Tapah Campus.
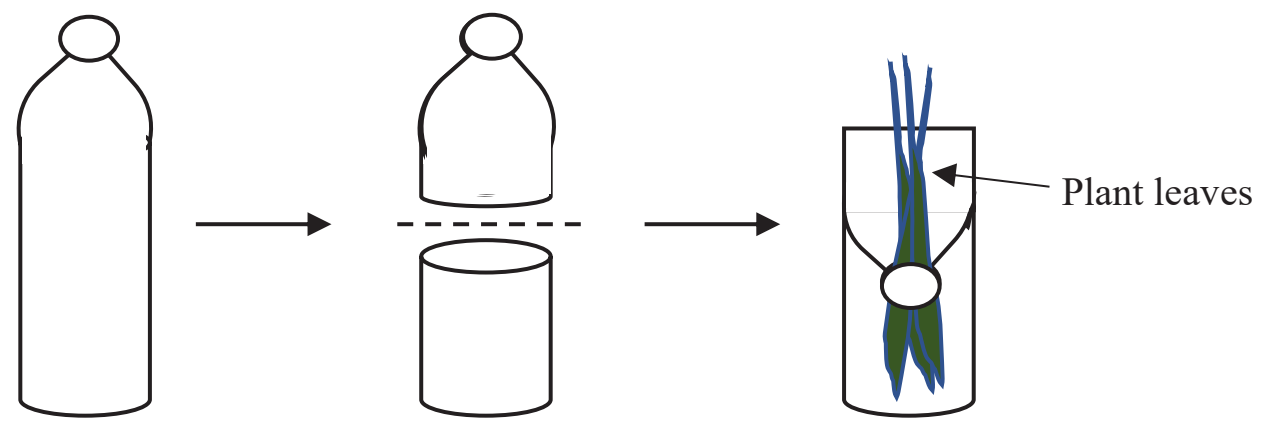

\section{Acclimatization of juveniles under laboratory conditions}

The juveniles were reared using $5 \mathrm{~L}$ plastic containers filled with aging tap water. The water depth was approximately 7.6 $\mathrm{cm}$ from the bottom of the containers. The animals were fed on fresh lettuce ad libitum and the rearing water was renewed every two days to prevent any unfavorable smells from the decomposition of leftover food and metabolic waste. No aeration was provided as the water current may have resuspended the food residue and snail waste in the water column. The temperature was kept at ambient, between $27^{\circ} \mathrm{C}-28^{\circ} \mathrm{C}$, and with normal photoperiodism (12L:12D). Acclimatization was conducted within two weeks, during which neither mating nor egg-laying incidences were detected in the rearing container. No snails died and no cannibalism was observed within the rearing population.

\section{Experimental design for feeding consumption and growth studies of juveniles served with individual plant species}

Only active juvenile individuals were selected for experimentation. The snails were starved for 24 hours before the beginning of the experiment. Food was selected from the fresh leaves of four different plants, i.e., C. longa, P. amaryllifolius, I. batatas and I. aquatica. All the plants were purchased from a wet market to ensure they were free from plant diseases or the pesticide residues used in natural conditions.

The experimental set-up consisted of 12 plastic containers representing four types of plants with three replicates. Each plastic container was an empty $500 \mathrm{~mL}$ mineral water bottle cut in half across the middle. The top bottle mouth was inverted and replaced on the top of the bottom part (Fig. 1). This technique was to allow the suspension of plant leaves from the bottle mouth, which was to hang straight to the bottom of the plastic bottle.

Fig. 1. Design of the experimental apparatus for juveniles fed on individual plant species. 
This design also helped to prevent the snails from escaping.

Each plastic container was half-filled with $200 \mathrm{~mL}$ of aging water and three individuals of juveniles were placed inside. Therefore, a total of nine individual juveniles were used for a single macrophyte species throughout the feeding experiment (total $n=36$ juveniles, since four species of macrophytes were used). Feeding regimes were served to all the replicated bottles by weighing $2.0 \mathrm{~g}$ of fresh plant leaves. A similar set-up was prepared for every plant leaf but without a snail inside, to determine the autogenic plant mass changes that were unrelated to feeding activities (Roa, 1992).

Meanwhile, the rearing water was renewed every two days, together with the replacement with new plant leaves $(2.0 \mathrm{~g})$. This was to avoid the snails dying due to waste accumulation and intraspecific competition. The unconsumed plant leaves were used to calculate the feeding consumption of the juveniles. Prior to this, the excess water was removed from the unconsumed leaves using blotting paper and the leaf mass was weighed. The initial plant mass was corrected for autogenic changes using the following equation:

$$
=\left(H o \times \frac{C f}{C o}\right)-H f
$$

where $H o$ and $H f$ represent the initial and final wet masses of the plant leaves exposed to herbivory activity, respectively, and
Co and Cf are the initial and final masses of the controls for autogenic changes (Stachowicz \& Hay, 1996). The feeding consumption is expressed as the amount of plants consumed by an individual snail (mg/snail/day). The observation was conducted for ten days.

Meanwhile, the snails' growth rates were determined by measuring their weight, i.e., the weight of an entire animal (the shell plus the body). Similarly, the snails' weights (mg) were measured and recorded every two days using a professional digital scale (CX Series, Dongguan Nancheng Changxie Electronic Products Factory, Guangdong, China). The growth curve is illustrated as a line graph and the growth rate (mg/snail/day) was calculated based on the snails' weight changes over the course of the experiment.

\section{Experimental design for food preference using multiple macrophytes species}

Based on the growth curve, we found that the juveniles could not survive longer under the feeding regime involving I. batatas. Therefore, we proceeded to experiment further on food preference based on three plant species, i.e., I. aquatica, P. amaryllifolius and C. longa. The experimental set-up was constructed using 1.5 L empty mineral water bottles on the horizontal plane. Along the length of the bottle, three holes were made at equal length intervals to allow the snails and plant leaves to be insert-

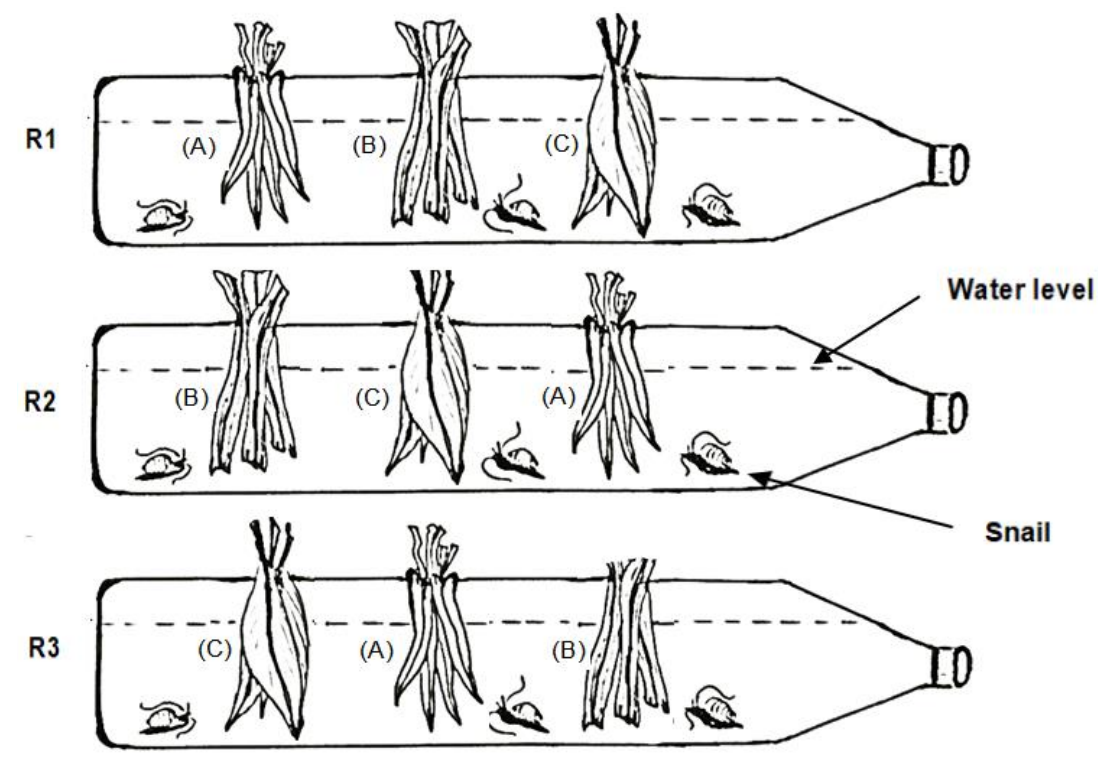

Fig. 2. Design of the experimental apparatus for juveniles fed on multiple macrophyte species. (A) Ipomoea aquatica; (B) Pandanus amaryllifolius; (C) Cucurma longa. 
ed during the feeding regimes (Fig. 2). The bottle was filled with rearing water up to nearly three-quarters of the bottle height $(1,200 \mathrm{~mL})$.

Inside the bottle, nine juvenile snails were stocked up and starved for 24 hours prior to the feeding regimes. Each snail was marked in order from one to nine. Thereafter, $2.0 \mathrm{~g}$ of every type of plant leaves were stitched and tied up with a fine string before being inserted through the holes. The plant leaves were hung in a straight position approximately $1 \mathrm{~cm}$ from the bottom. Observations were conducted every two hours for a total of 12 hours, from $6 \mathrm{pm}$ to $6 \mathrm{am}$ the next day due to the nocturnal behavior of the species. This experiment was set up in triplicate. In each replicate, the plant leaves were inserted through alternate holes (refer to Fig. 2) to facilitate an equal chance of contact between the leaves and the snails. A similar set-up was prepared with no snails, the purpose of which was to monitor the autogenic changes in the plant biomass.

The percentage of snails attracted to each plant and the plant leaves that had been eaten were recorded every two hours to represent the feeding preference. Similarly, the feeding preference was measured from the leftover plant mass after this had been corrected for autogenic changes by incorporating the control setup, according to the work of Stachowicz \& Hay (1996). The units of leftover plant leaves are expressed in milligrams (mg).

\section{Statistical analysis}

Analysis of all the experimental data was performed using IBM SPSS Statistic 25.0. Data on the growth rate, feeding consumption of individual plants and total feeding consumption of multiple plants were analyzed using a parametric test, the one-way ANOVA. The normality assumption is achieved when Levene's test reveals an insignificant result $(p>0.05)$. The significant differences between the groups were assessed at a $0.05 \%$ level of probability using Tukey's multiple comparison test.

Data on the growth pattern and feeding preference for multiple plant species failed to follow the normal distribution and could not be transformed to achieve normality. Therefore, we chose a non-parametric test (Kruskal-Wallis) to analyze the experimental data. For comparisons between the groups, the data were analyzed using the Mann-Whitney test at $p<0.05$.

\section{Results}

\section{Growth pattern}

The growth pattern of juvenile $P$. canaliculata varies according to the type of macrophyte. Based on Fig. 3, the growth pattern of juveniles fed on I. aquatica significantly increased during the ten days of observation (Kruskal-Wallis; $p<0.05$; Table 1). In contrast, the growth pattern of juveniles fed on P. amaryllifolius slowly increased; it was apparent that the increment was not significant during the ten days of observation (Kruskal-Wallis; $p$ $>0.05$; Table 1). An increase in the snails' weight was observed in the first two days for juveniles fed on C. longa. Subsequently, the snail weight seemed to decrease consistently until the end of the experiment. However, the decrease in the growth pattern until the end of the experiment was also not significant (Kruskal-Wallis; $p>0.05$; Table 1). No snail deaths or mating activities were observed during the experiment under the feeding regimes of I. aquatica, P. amaryllifolius, and C. longa.

Finally, the juveniles fed on I. batatas could not reveal a

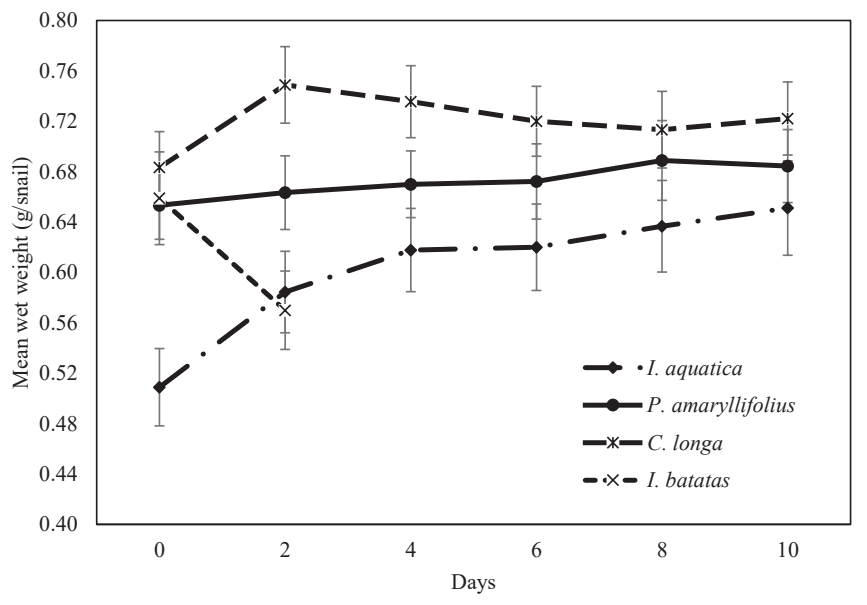

Fig. 3. Growth pattern of juveniles Pomacea canaliculata based on mean wet weight (g/snail) fed on individual plant species within 10 days duration. Bars denote standard error ( $\mathrm{N}=9$ for each plant species; Total $\mathrm{N}=27$ ). I. aquatica, Ipomoea aquatica; P. amaryllifolius, Pandanus amaryllifolius; C. longa, Cucurma longa; I. batatas, Ipomoea batatas.

Table 1. Statistical comparison using Kruskal-Wallis on the growth pattern (mean wet weight; g/snail) served with individual plant species during ten days of observation

\begin{tabular}{llll}
\hline Plant species & $d f$ & $x^{2}$ & $p$-value \\
\hline Ipomoea aquatica & 5 & 11.398 & $0.044^{*}$ \\
Pandanus amaryllifolius & 5 & 1.382 & $0.926^{\mathrm{ns}}$ \\
Cucurma longa & 5 & 5.468 & $0.361^{\mathrm{ns}}$ \\
\hline
\end{tabular}

${ }^{*} p<0.05 ; \mathrm{ns}$, insignificant result; note that result on I. batatas is unavailable due to the death of the snails on day 2 . 
growth pattern of the snail weight decreasing from day 0 of the experiment. By day 2, all the juveniles had died. Even though the dead snails were replaced, and the experiment was repeated three times, similar results were observed at the end of day 2 . We concluded that $I$. batatas was not a suitable diet on which the juvenile snails could survive, so I. batatas was excluded as a diet in further experiments.

Feeding consumption and growth studies based on individual macrophytes

The feeding consumption of the juveniles was calculated based on the amount of leaves eaten by each individual snail. The ANOVA analysis showed that there was a significant difference in the feeding consumption of juveniles fed on different types of macrophyte (One-way ANOVA; $p<0.05$; Table 2). The juveniles consumed significantly more I. aquatica than P. amaryllifolius and C. longa (Tukey test; $p<0.05$; Fig. 4A). The juveniles consumed the lowest amount of the macrophyte $P$. amaryllifolius. However, the feeding consumption for $P$. amaryllifolius and C. longa was not significantly different (Tukey test; $\mathrm{p}>0.05$; Fig. 4A).

Similarly, the growth rate of the juveniles was significantly affected in respect to the different types of macrophytes consumed (One-way ANOVA; $p<0.05$; Table 2). The growth rate of the juveniles was the highest with the consumption of $I$. aquatica, but the snail weight did not differ significantly from the weight obtained by the juveniles that consumed $P$. ama-

Table 2. Analysis of one-way ANOVA on the growth rate and feeding rate of Pomacea canaliculata juveniles based on the consumption of individual plant species

\begin{tabular}{|c|c|c|c|c|c|}
\hline Source & $d f$ & SS & MS & $F$-value & $p$-value \\
\hline \multicolumn{6}{|c|}{ Feeding consumption } \\
\hline Between group & 2 & $189,825.43$ & $94,912.72$ & 34.60 & $0.001^{*}$ \\
\hline Within group & 6 & $16,459.68$ & $2,743.28$ & & \\
\hline Total & 8 & $206,285.11$ & & & \\
\hline \multicolumn{6}{|l|}{ Growth rate } \\
\hline Between group & 2 & 335.79 & 167.90 & 86.04 & $0.001^{*}$ \\
\hline Within group & 6 & 11.71 & 1.95 & & \\
\hline
\end{tabular}
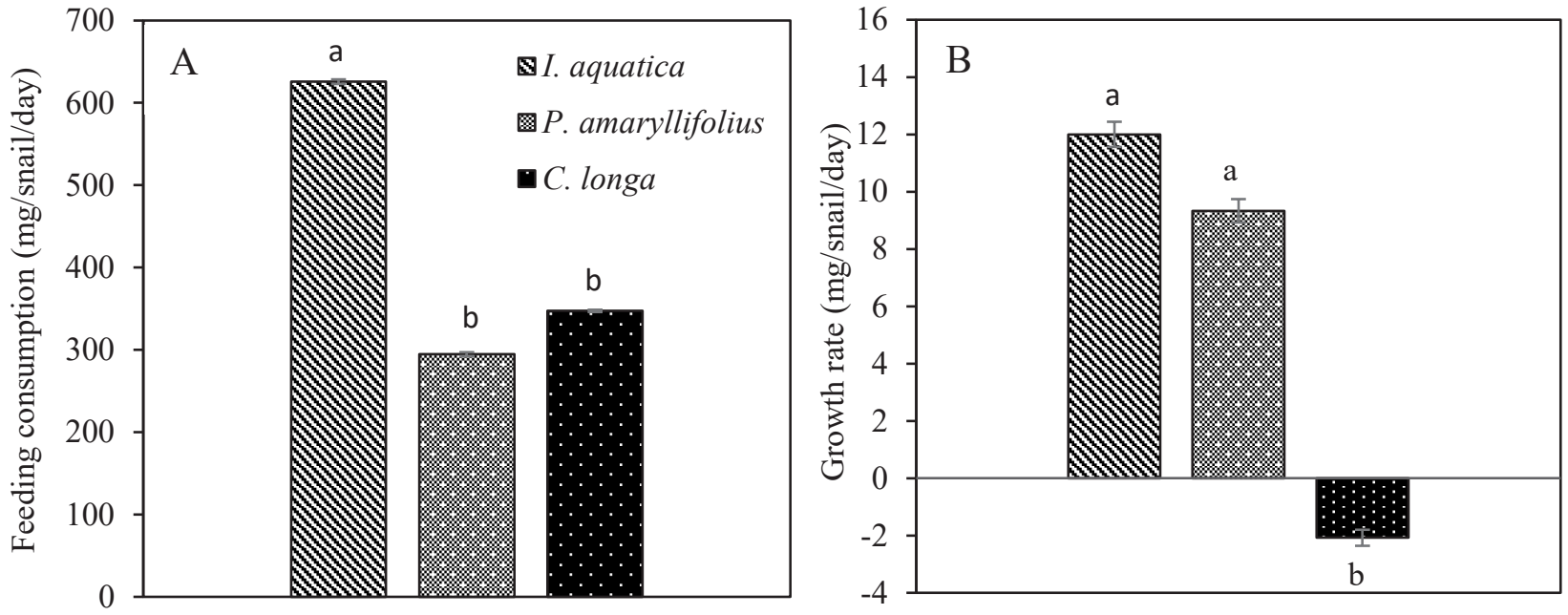

Fig. 4. Feeding consumption ( $\mathrm{mg} / \mathrm{snail} / \mathrm{day}$ ) and B: growth rate ( $\mathrm{mg} / \mathrm{snail} / \mathrm{day})$ of juveniles Pomacea canaliculata served to individual plant species within 10 days observation. Bars denote standard error ( $\mathrm{N}=9$ for each plant species; Total $\mathrm{N}=27)$. I. aquatica, Ipomoea aquatica; P. amaryllifolius, Pandanus amaryllifolius; C. Ionga, Cucurma longa. 
ryllifolius (Tukey test; $p>0.05$; Fig. 4B). The growth rate of the juveniles was significantly the lowest with the consumption of $C$. longa (Tukey test; $p<0.05$; Fig. 4B).

\section{Snails' feeding preference and total feeding consumption served with multiple macrophyte species}

With exposure to multiple macrophytes species, the juveniles demonstrated feeding preference trends, as shown in Fig. 5. At the beginning of the experiment, a small percentage of juveniles were attracted only to $C$. longa leaves. After six hours of observation (from 18:00 to 00:00), a small percentage of juveniles started to explore all the given plant species. However, the juveniles did not reveal any significant feeding preferences among the plant species from 18:00 until 00:00 (Kruskal-Wallis; $p>0.05$; Table 3). A significant feeding preference was noticeable from 02:00 until the end of the observation at 06:00 (Kruskal-Wallis; $p<0.05$; Table 3 ). Most juveniles significantly preferred to feed on I. aquatica (Mann-Whitney; $p<0.05$; Fig. 5) while less preference was observed for $P$. amaryllifolius and C. longa. The difference in feeding preference among the juveniles for P. amaryllifolius and for $C$. longa was not significantly different (Mann-Whitney; $p>0.05$; Fig. 5).

The amount of leaves consumed by the juveniles repre- sented the total feeding consumption, thereby expressing the feeding preference of the juveniles during a 12-hour observation (18:00 until 06:00). At the end of the experimentation, the total feeding consumption was found to be significantly affected by the types of macrophytes (one-way ANOVA; $p<0.05$; Table 4). The highest total feeding consumption was significantly directed toward I. aquatica (Tukey test; $p<0.05$; Fig. 6). From the visual observation, some juveniles were attracted to the leaves of $P$. amaryllifolius and C. longa. However, based on the nega-

Table 3. Statistical comparison using Kruskal-Wallis on snail feeding preference (\%) versus plant species every two hours for 12 hours of observation

\begin{tabular}{llll}
\hline Hours & $d f$ & $x^{2}$ & $p$-value \\
\hline $18: 00$ & 2 & 2.000 & $0.368^{\text {ns }}$ \\
$20: 00$ & 2 & 0.444 & $0.801^{\text {ns }}$ \\
$22: 00$ & 2 & 0.095 & $0.953^{\text {ns }}$ \\
$00: 00$ & 2 & 1.556 & $0.459^{\text {ns }}$ \\
$02: 00$ & 2 & 6.000 & $0.050^{*}$ \\
$04: 00$ & 2 & 6.720 & $0.035^{*}$ \\
$06: 00$ & 2 & 6.222 & $0.045^{*}$ \\
\hline
\end{tabular}

" significant at $p<0.05$; ns is insignificant result. $d f$, degree of freedom.

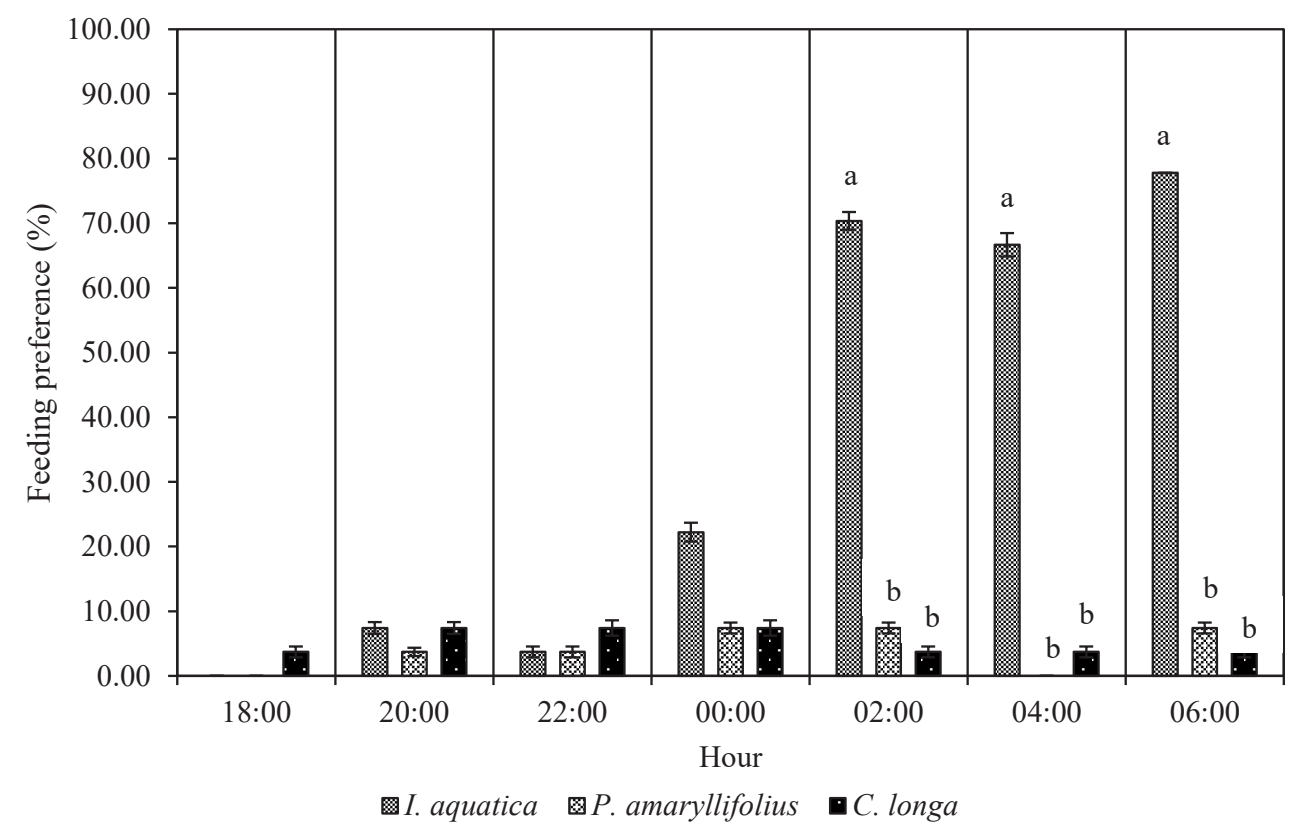

Fig. 5. Feeding preference (\%) of juveniles Pomacea canaliculata served to multiple plant species by hours. Bars denote standard error ( $\mathrm{N}=9$ for each plant species; Total $\mathrm{N}=27$ ). I. aquatica, Ipomoea aquatica; P. amaryllifolius, Pandanus amaryllifolius; $C$. longa, Cucurma longa. 
Table 4. Analysis of one-way ANOVA on the total feeding consumption of juveniles Pomacea canaliculata served with multiple plants

\begin{tabular}{|c|c|c|c|c|c|}
\hline Source & $d f$ & SS & MS & F-value & $p$-value \\
\hline \multicolumn{6}{|c|}{ Total feeding consumption } \\
\hline Between group & 2 & $1,207,266.67$ & $603,633.34$ & 59.24 & $0.001^{*}$ \\
\hline Within group & 6 & $61,133.34$ & $10,188.89$ & & \\
\hline Total & 8 & $1,268,400.00$ & & & \\
\hline
\end{tabular}

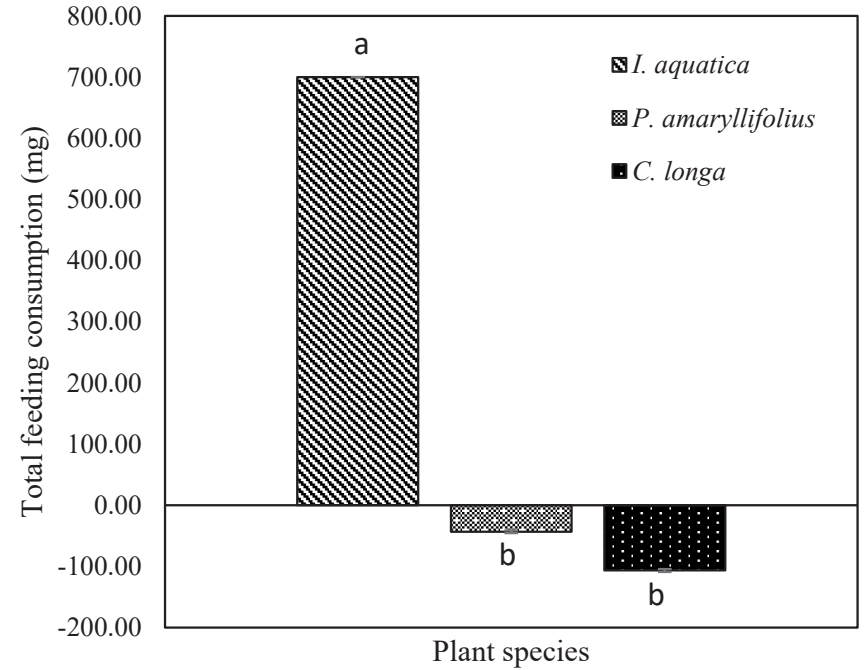

Fig. 6. Total feeding consumption $(\mathrm{mg})$ of juveniles Pomacea canaliculata served to multiple macrophyte species within 12 hours observation. Bars denote standard error ( $\mathrm{N}=9$ for each plant species; Total $\mathrm{N}=27$ ). I. aquatica, Ipomoea aquatica; $P$. amaryllifolius, Pandanus amaryllifolius; C. longa, Cucurma longa.

tive values obtained, the total feeding consumption was almost unavailable. The statistical analysis revealed no significant effect of the total feeding consumption for P. amaryllifolius or C. longa (Tukey test; $p>0.05$; Fig. 6).

\section{Discussion}

\section{Growth pattern}

Numerous studies in the literature have documented the growth pattern of golden apple snails, with an emphasis on P. canaliculata. However, the growth pattern assessments vary according to the parameters selected for the assessment. In a long-term study by Arfan et al. (2015), the growth pattern of P. canaliculata was illustrated based on the animal's shell length. However, the shell width and height were assessed to reveal the growth pattern in studies by Lach et al. (2000) and Yoshida et al. (2009). In these studies, the length of the experiments extended for 27 and 30 weeks, respectively, and resulted in trends of increasing growth over time. Our study was conducted over a shorter period of ten days and the increasing trend of the growth pattern was based on the snail weight, which is the combination of the weight of the shell and the wet body inside. The use of the snail weight as a growth parameter was also adopted by Chaichana \& Sumpan (2014) and Carlsson \& Lacoursière (2005).

In gastropod species, the growth pattern may be regulated by the types of plants, while the measurement of the snail weight is more sensitive than the measurements of shell length/width in portraying the effects of food. Certainly, the shell growth requires a calcium-rich diet and a longer observation period to obtain any significant shell growth (Egonmwan, 2008). Our study revealed a significant result, whereby the mean snail weight of $P$. canaliculata fed on $I$. aquatica changed over time, indicating a trend of increasing growth rate. However, feeding the snails with $P$. amaryllifolius showed a slight increment in the mean snail weight, although traces of the effects of grazing were observed on the leaf surfaces. The growth pattern of the snails fed on both $P$. amaryllifolius and C. longa was not significant over the period. Our results are partly consistent with the feeding study by Carlsson \& Lacoursière (2005) on the macrophytes I. aquatica, Lemna minor, and Eichornia crassipes. They demonstrated that the growth pattern of $P$. canaliculata fed on I. aquatica consistently showed an increasing trend during 30 days of observation. However, the growth pattern for C. longa (our study) and E. crassipes (Carlsson \& Lacoursière, 2005) was similar, with the growth increasing at the beginning and subsequently decreasing.

We also found that the juvenile snails fed on I. batatas showed a decreasing growth trend. No feeding activities were available as no grazing effects were detected on the leaves. Con- 
sequently, all the juveniles died on day 2, suggesting the incompatibility of the plant as a food source for P. canaliculata. This finding was unexpected, considering that $I$. batatas belongs to the same family as I. aquatica. The physical characteristics of the leaves of both species are not much different, both being soft and less fibrous. However, a similar finding was reported when the growth rate of the land snail, Allopeas gracile, was deterred in a feeding regime based on I. batatas (Capinera, 2017). In the recent study by Noorshilawati et al. (2020), the leaves of I. batatas were analyzed; they apparently contained saponin, which led to molluscicide activity in P. canaliculata. Evidently, the toxicity effect of $I$. batatas was demonstrated by the snails within 48-72 hours.

In summary, the growth pattern can be expressed through many physical characteristics, such as shell length, shell width, and snail weight. In addition, the types of plant assimilated for feeding consumption regulate the growth pattern significantly. Among the macrophytes species, I. aquatica positively showed an increasing trend in the growth pattern, while P. amaryllifolius, I. batatas, and C. longa did not.

\section{Feeding consumption and growth rate of juveniles fed on individual macrophytes}

We produced a detailed assessment of the feeding consumption and growth rate of each juvenile served with each macrophyte species. In this study, the juveniles consumed more I. aquatica than P. amaryliifolius and C. longa. The growth rate was the fastest in juveniles that consumed I. aquatica but the growth rate did not differ in juveniles that consumed P. amaryliifolius. A study by Qiu \& Kwong (2009) also revealed that P. canaliculata that consumed I. aquatica grew much faster than when feeding on the other plant species. The study by Yam et al. (2016) also found that the snails consumed more Nymphoides coreana than Commelina communis but, surprisingly, the snails grew at an equal rate. In another feeding study, $P$. canaliculata consumed more of the macrophyte Egeria najas than Ceratophyllum demersum but snails fed on $C$. demersum grew much faster than those fed on E. najas (Cruz et al., 2015). These results likely indicated that the feeding consumption did not determine the growth rate. Instead, the quality of the macrophytes was of great importance.

Although an analysis of macrophyte quality was absent in our study, extensive information is available in the literature. This is summarized in Table 5, with emphasis on the proximate analysis of each macrophyte species. It is well understood that the principal contribution to the growth process of gastropods is made by the protein (Chelladurai, 2017) and carbohydrate (Livingstone \& Zwaan, 1983) content in their food consumption. Among all the plant species used, the protein content is the highest in I. aquatica, followed by $P$. amaryllifolius and $C$. longa. Meanwhile, the carbohydrate content is the highest in $P$. amaryllifolius, followed by I. aquatica and C. longa. While our findings revealed the growth rate of the snails was significantly higher with $I$. aquatica and P. amaryllifolius, these results might be due to high protein and carbohydrate content in I. aquatica and $P$. amaryllifolius, respectively.

In comparison to other herbivorous organisms, the use of fresh $I$. aquatica leaves in the diet enhanced the growth rate of rabbits (Nakkitset et al., 2008; Samkol et al., 2006). In fact, a diet

Table 5. Proximate composition of each plant species based on previous studies

\begin{tabular}{|c|c|c|c|c|c|c|}
\hline Plant species & Protein (\% DW) & Carbohydrate (\% DW) & Crude fiber (\% DW) & $\begin{array}{l}\text { Total phenolics } \\
\text { (mg GAE/100 g) }\end{array}$ & Total flavonoids & References \\
\hline \multirow[t]{6}{*}{ Ipomoea aquatica } & 29.46 & & 7.90 & & & Ali \& Kaviraj (2018) \\
\hline & 30.00 & & & & & Wafar \& Tarimbuka (2016) \\
\hline & 25.60 & 47.95 & 7.62 & & & Adedokun et al. (2019) \\
\hline & 17.84 & 35.34 & & & & Vishwakarma \& Dubey (2011) \\
\hline & & $42.18 \%$ & $1.20 \%$ & & & Igwenyi et al. (2011) \\
\hline & & & & $0.22 \%$ & & Yam et al. (2016) \\
\hline \multirow[t]{2}{*}{ Pandanus amaryllifolius } & $16.0-19.0$ & $70.0-74.0$ & & $316-344$ & $17-19$ & Suryani et al. (2020) \\
\hline & & & & 356.4 & & Yan \& Asmah (2010) \\
\hline \multirow[t]{4}{*}{ Cucurma longa } & 13.9 & & 13.4 & & & Bhowmik et al. (2008) \\
\hline & 6.00 & 43.3 & 34.5 & 3.65 & 4.99 & Kim et al. (2019) \\
\hline & & & & 348.8 & & Yan \& Asmah (2010) \\
\hline & & & & 230.0 & & Chan et al. (2008) \\
\hline
\end{tabular}


containing I. aquatica is considered nutritious as it is the usual fishmeal given to Nile Tilapia fry, Oreochromis niloticus (Yousif et al., 2019), common carp fingerlings, Cyprinus carpio (Thy et al., 2008) and rohu fingerlings, Labeo rohita (Ali \& Kaviraj, 2018). I. aquatica is a good source of carbohydrate and protein (Nakkitset et al., 2008); it is also rich in vitamins (Igwenyi et al., 2011) and trace minerals. In addition, I. aquatica has generally higher nutrient content (N \& P) but has poorer physical (toughness, cellulose, lignin) and chemical defensive characteristics (Yam et al., 2016). In fact, it has been widely served as feed to all kinds of animals, including humans.

P. amaryllifolius is also a common macrophyte in wetland ecosystems and is popularly known for its scented leaves. Our study found that the snails that consumed $P$. amaryllifolius exhibited a high growth rate, although fewer leaves were consumed in comparison to I. aquatica. This was possibly due to its higher carbohydrate and protein content, as reported in Table 4.0, which promoted the growing process of the snails. There is a lack of information in the literature on the use of fresh P. amaryllifolius to promote animal growth. However, we found that a diet supplemented with $P$. amaryllifolius significantly increased the egg production (Sa-nguanphan, 2010) and egg quality of laying hens (Tongdonkham et al., 2018).

Meanwhile, the growth rate of snails that consumed $C$. longa was the slowest. However, the recent study by Md Latip et al. (2020) revealed that the chemical content in C. longa leaves induced a molluscicidal effect on $P$. canaliculata. These molluscicidal effects extend to other gastropod species such as Biomphalaria pfeifferi, Bulinus globosus, and Lymnaea natalensis (Omobhude et al., 2019). Therefore, apart from its addition as a food ingredient and biomolluscicide, our study reveals that feeding on $C$. longa leaves deterred the growth rate of the snails.

\section{Feeding preference and total feeding consumption using multiple macrophytes species}

Tropical wetlands contain a high density of macrophyte species with different physical characteristics and different metabolic products. This may affect the grazing ability of herbivores, including the golden apple snail, P. canaliculata. Among the gastropods, $P$. canaliculata is a powerful grazer since their mouthparts are well-equipped with a feeding organ called the radula, a teethlike-organ with a rasping tongue (Martín \& Negrete, 2007). The radula enables the snails to graze on macrophyte species with different physical leaf textures. Many studies have reported that $P$. canaliculata displayed a higher feeding rate and stronger grazing pressure on macrophytes in comparison to other species of apple snails such as Pila scutata (Chaichana \& Sumpan, 2014), P. maculata (Arfan et al., 2015), P. haustrum (Morrison \& Hay, 2011), Pila angelica and Pila pesmei (Pradabphetrat et al., 2018). Therefore, P. canaliculata is the most invasive and successful snail in colonizing wetland ecosystems.

From our findings, the snails grazed ferociously on I. aquatica during the 12-hour observation. The feeding preference was significantly shown after six hours of the plant's introduction, which consequently demonstrated the highest total feeding consumption. The snail's preference for I. aquatica was also demonstrated in the study by Yam et al. (2016), which provided additional information on the physical and chemical composition of $I$. aquatica. It was reported that I. aquatica is generally higher in nutrient content (N: $4.3 \%$ and P: $0.7 \%$ ) but lower in physical properties (in terms of toughness, cellulose and lignin) and chemical defensive characteristics (i.e., phenolics) (refer to Table 4). In contrast, Carlsson et al. (2004) found that I. aquatica was the least preferable food, in comparison to duckweed, L. minor and water hyacinth, E. crassipes. The main reason was the physical characteristics of both duckweed and water hyacinth, which are more succulent than water spinach, I. aquatica.

Our study showed that both P. amaryllifolius and C. longa were grazed on initially but became less preferable six hours later. Unlike $I$. aquatica, the leaves of both $P$. amaryllifolius and C. longa produce a strong, unique smell, indicating the presence of high levels of chemical compounds. It appears that this snail prefers neutral (non-aromatic) macrophytes more than aromatic ones. A study by Qiu et al. (2011) emphasized that the snail's feeding consumption was not so much determined by the plant's freshness but more by its defensive chemicals (i.e., phenolic content). Furthermore, $P$. canaliculata was reported to choose a floating species first before turning to submerged and emergent macrophytes (Chaichana \& Sumpan, 2014). In this case, I. aquatica was the floating macrophyte while P. amaryllifolius and C. longa were the emergent species.

Likely, $P$. canaliculata exhibits generalist feeder characteristics after a short period of exposure and shifts to become a selective feeder thereafter. Therefore, we agreed with Pradabphetrat et al. (2018), Carlsson \& Lacoursière (2005) and Lach et al. (2000) that $P$. canaliculata has the ability of food selection and exhibits a preference for certain macrophytes, in both laboratory and field observations. Given a limited choice of plants, they behave as generalist feeders but with an unlimited diversity of plants, they show a feeding preference for grazeable, neutral 
and digestible plants. In both situations, the herbivory effects by P. canaliculata are significantly evident on macrophyte species.

\section{Conclusion}

In conclusion, juveniles of $P$. canaliculata demonstrated a stronger herbivory effect on I. aquatica than they did on P. amaryllifolius and C. longa. Although in the individual feeding experiment the snail could consume all the macrophytes species, the growth rate was adversely affected using $C$. longa. It is widely acknowledged that tropical wetlands contain a high diversity of macrophytes, which are directly involved in ecosystem services. I. aquatica is a floating macrophyte that plays an important role in effective nutrient uptake to prevent eutrophication in the ecosystem. It also has been manipulated for bioremediation to remove excessive levels of nitrogen and phosphorus, which eventually increases the water quality index. Therefore, the introduction of $P$. canaliculata exposes soft vascular macrophytes with similar characteristics to I. aquatica to grazing pressure and threatens the biodiversity in wetland ecosystems. Although efforts have been made to introduce $P$. canaliculata as a weed controller, the idea is strongly inadvisable because an ecosystem infested with this snail serves as a holding reservoir for the proliferation of this population, which may increase the invasiveness of this species into non-infested areas. We recommend the cultivation of $C$. longa or $I$. batatas as a biological control to reduce the herbivory of this snail on infested ecosystems. However, a detailed study must be conducted on the mode of action of these plants in relation to the physiology and feeding behavior of the snail.

\section{Competing interests}

No potential conflict of interest relevant to this article was reported.

\section{Funding sources}

The University Technology MARA awarded a scholarship to the researcher during her sabbatical leave to conduct the scientific research. Equipment and supplies were funded by the Faculty of Applied Science, University Technology MARA of Perak Branch Tapah Campus.

\section{Acknowledgements}

Acknowledgement also goes to Assistant Science Officer, Mr. Mohd Rahmat Mohammad Razali for his kind technical assistance in the field and laboratory works.

\section{Availability of data and materials}

Upon reasonable request, the datasets of this study can be available from the corresponding author.

\section{Ethics approval and consent to participate}

This article does not require IRB/IACUC approval because there are no human and animal participants.

\section{ORCID}

Hasnun Nita Ismail https://orcid.org/0000-0003-2277-2397

Wan Nurul Hidayah Wan Anuar

https://orcid.org/0000-0002-1703-3007

Noormawaty Mohammad Noor

https://orcid.org/0000-0003-4284-9312

\section{References}

Adedokun MA, Ogundiran MA, Alatise SP. Preliminary assessment of water spinach (Ipomoea aquatica) and morning glory (Ipomoea asarifolia) leaves meals as non-conventional fish feed stuffs. Int J Fish Aquat Stud. 2019;7:446-50.

Ahmad AM, Abdullahi AH, Ahmad NB. Biological control of aquatic macrophytes and ecological implication: a review. World J Pharm Med Res. 2019;5:12-30.

Ali S, Kaviraj A. Aquatic weed Ipomoea aquatica as feed ingredient for rearing rohu, Labeo rohita (Hamilton). Egypt J Aquat Res. 2018;44:321-5.

Arfan AG, Muhamad R, Omar D, Nor Azwady AA, Manjeri G. Comparative life cycle studies of Pomacea maculata and Pomacea canaliculata on rice (Oryza sativa). Pak J Agric Sci. 2015;52:1075-9.

Arfan AG, Muhamad R, Omar D, Nor Azwady AA, Manjeri G. Distribution of two Pomacea spp. in rice fields of peninsular Malaysia. Annu Res Rev Biol. 2014;4:4123-36.

Bhowmik S, Chowdhury SD, Kabir MH, Ali MA. Chemical composition of some medicinal plant products of indigenous origin. Bangladesh Vet. 2008;25:32-9.

Carlsson NOL, Brönmark C, Hansson LA. Invading herbivory: the golden apple snail alters ecosystem functioning in Asian wetlands. Ecology. 2004;85:1575-80.

Carlsson NOL, Lacoursière JO. Herbivory on aquatic vascular plants by the introduced golden apple snail (Pomacea canaliculata) in Lao PDR. Biol Invasions. 2005;7:233-41.

Capinera JL. Biology and food habits of the invasive snail Allopeas gracile (Gastropoda: Subulinidae). Florida Entomol. 
2017;100:116-23.

Chaichana R, Sumpan T. The potential ecological impact of the exotic snail Pomacea canaliculata on the Thai native snail Pila scutata. Sci Asia. 2014;40:11-15.

Chan EWC, Lim YY, Wong LF, Wong LF, Lianto FS, Wong SK, et al. Antioxidant and tyrosinase inhibition properties of leaves and rhizomes of ginger species. Food Chem. 2008;109:477-83.

Chelladurai G. Influence of diets on growth and biochemical parameters of Babylonia spirata. Geol Ecol Landsc. 2017;1:162-6.

Clarkson BR, Ausseil AGE, Gerbeaux PJR. Wetland ecosystem services. In: Dymond JR, editor. Ecosystem services in New Zealand: conditions and trends. Lincoln, New Zealand: Manaaki Whenua Press; 2013.

Cruz C, Silva AF, Venturini FP, Garlich N, Pitelli RLCM, Pitelli RA. Food preference and consumption of aquatic macrophytes submerged by snail Pomacea canaliculata. Planta Daninha. 2015;33:433-9.

de Brito FC, Joshi RC. The golden apple snail Pomacea canaliculata: a review on invasion, dispersion, and control. Outlooks Pest Manag. 2016;27:157-63.

Egonmwan RI. Effects of dietary calcium on growth and oviposition of the African land snail Limicolaria flammea (Pulmonata: Achatinidae). Rev Biol Trop. 2008;56:333-43.

Fang L, Ki Wong P, Lin L, Lan C, Qiu JW. Impact of invasive apple snails in Hong Kong on wetland macrophytes, nutrients, phytoplankton, and filamentous algae. Freshw Biol. 2010;55:1191-204.

Gamarra-Luques C, Giraud-Billoud M, Castro-Vazquez A. Reproductive organogenesis in the apple snail Pomacea canaliculata (Lamarck, 1822), with reference to the effects of xenobiotics. J Molluscan Stud. 2013;79:147-62.

Gilal AA, Muhamad R, Omar D, Abdul Aziz NA, Gnanasegaram M. Foes can be friends: laboratory trials on invasive apple snails, Pomacea spp. preference to invasive weed, Limnocharis flava (L.) buchenau compared to rice, Oryza sativa L. Pak J Agric Sci. 2016;48:673-9.

Ghermandi A, van den Bergh JCJM, Brander LM, Nunes PALD. The economic value of wetland conservation and creation: a meta-analysis. Milano: Fondazione Eni Enrico Mattei (FEEM); 2008. FEEM Working Paper No. 79.2008.

Gibbs JP. Wetland loss and biodiversity conservation. Conserv Biol. 2000;14:314-17.

Igwenyi IO, Offor CE, Ajah DA, Nwankwo OC, Ukomah JI, Aja
PM. Chemical composition of Ipomoea aquatica (green Kangkong). Int J Pharma Bio Sci. 2011;2:B-593-8.

Ip KKL, Qiu JW. Invasive apple snails: ecology and management in Hong Kong. In: Joshi RC, Cowie RH, Sebastian LS, editors. Biology and management of invasive apple snails. Pampanga: Pampanga State Agricultural University; 2017. p. 145-66.

Joshi RC, Sebastian LS. Global advances in ecology and management of golden apple snails. Manila, Philippine Rice Research Institute; 2006.

Kim S, Ko SC, Kim YS, Ha SK, Park HY, Park Y, et al. Determination of Curcuma longa L. (turmeric) leaf extraction conditions using response surface methodology to optimize extraction yield and antioxidant content. J Food Qual. 2019:1-8.

Lach L, Britton DK, Rundell RJ, Cowie RH. Food preference and reproductive plasticity in an invasive freshwater snail. Biol Invasions. 2000;2:279-88.

Livingstone DR, Zwaan AD. 5 - Carbohydrate metabolism of gastropods. In: Hochachka PW, editor. Metabolic biochemistry and molecular biomechanics. New York, NY: Academic Press; 1983 p. 177-242.

Lodge DM. Herbivory on freshwater macrophytes. Aquat Bot. 1991;41:195-224.

Martín SM, Negrete LHL. Radular ultrastructure of South American Ampullariidae (Gastropoda: Prosobranchia). Braz J Biol. 2007;67:721-6.

Md Latip SNH, Ibrahim R, Che Mohd Ramli NK, Clement MU. Molluscicidal activity of fresh leaves from Curcuma longa and Piper betle essential oil against Pomacea canaliculata. ASM Sci J. 2020;13:82-89.

Morrison WE, Hay ME. Feeding and growth of native, invasive and non-invasive alien apple snails (Ampullariidae) in the United States: invasives eat more and grow more. Biol Invasions. 2011;13:945-55.

Nakkitset S, Mikled C, Ledin I. Effect of feeding head lettuce, water spinach, ruzi grass or Mimosa pigra on feed intake, digestibility and growth in rabbits. Asian-Australas J Anim Sci. 2008;21:1171-7.

Naylor R. Invasions in agriculture: assessing the cost of the golden apple snail in Asia. Ambio. 1996;25:443-8.

Noorshilawati AA, Nur Suraya A, Siti Rossiyah S. Molluscicidal activity of Ipomoea batatas leaf extracts against Pomacea canaliculata (golden apple snail). Food Res. 2020;4:131-7.

Omobhude ME, Morenikeji OA, Oyeyemi OT. Molluscicidal 
activities of curcumin-nisin polylactic acid nanoparticle (PLA) on adult snail intermediate hosts of Schistosomes and Fasciola spp. Adv Res Life Sci. 2019;3:28-32.

Pradabphetrat P, Aroonsrimorakot S, Freder L, Tosh C, Piyapong C. A comparison of feeding behaviour and preferences of native and non-native invasive apple snail in Thailand. Chiang Mai J Sci. 2018;45:2294-302.

Qiu JW, Chan MT, Kwong KL, Sun J. Consumption, survival and growth in the invasive freshwater snail Pomacea canaliculata: does food freshness matter? J Molluscan Stud. 2011;77:189-95.

Qiu JW, Kwong KL. Effects of macrophytes on feeding and life-history traits of the invasive apple snail Pomacea canaliculata. Freshw Biol. 2009;54:1720-30.

Ricciardi A, Cohen J. The invasiveness of an introduced species does not predict its impact. Biol Invasions. 2007;9:309-15.

Roa R. Design and analysis of multiple-choice feeding-preference experiments. Oecologia. 1992;89:509-15.

Sa-nguanphan S. Effects of Pandanus amaryllifolius Roxb. supplementation on egg production performance and egg quality under different housing systems. Agric Nat Sci. 2010;44:191-5.

Samkol P, Preston TR, Ly J. Effect of increasing offer level of water spinach (Ipomoea aquatica) on intake, growth and digestibility coefficients of rabbits. Livest Res Rural Dev. 2006;18:25.

Simberloff D. Invasive species. In: Sodhi NS, Ehrlich PR, editors. Conservation biology for all. Oxford: University Press; 2010. p. 131-52.

Stachowicz JJ, Hay ME. Facultative mutualism between an herbivorous crab and a coralline alga: advantages of eating noxious seaweeds. Oecologia. 1996;105:377-87.

Suryani CLS, Wahyuningsih TD, Supriyadi S, Santoso U. The potential of mature pandan leaves as a source of chlorophyll for natural food colorants. J Teknologi dan Industri Pangan. 2020;31:127-37.

Thy S, Borin K, Vanvuth T, Buntha P, Preston TR. Effect of water spinach and duckweed on fish growth performance in poly-culture ponds. Livest Res Rural Dev. 2008;20:16.

Tongdonkham S, Chedeng S, Morlor A. Supplementation of Leucaena leucocephala and Pandanus amaryllifolius Roxb in laying diet on performance and egg quality. J Agric Res Ext. 2018;35:538-44.

Tu DV, Nha NP, Joshi RC. Invasive apple snails (Pomacea spp.) in Vietnam: short review. Aquac Asia Mag. 2018;22.
Vishwakarma KL, Dubey V. Nutritional analysis of indigenous wild edible herbs used in eastern Chhattisgarh, India. Emir J Food Agric. 2011;23:554-60.

Wafar RJ, Tarimbuka LI. Effects of substituting groundnut cake with water spinach (Ipomoea aquatica) leaf meal on performance, carcass yield and blood profile of weaner rabbit. FUW Trends Sci Technol J. 2016;1:238-42.

Whitney KD, Gabler CA. Rapid evolution in introduced species, 'invasive traits' and recipient communities: challenges for predicting invasive potential. Divers Distrib. 2008;14:56980.

Wong PK, Liang Y, Liu NY, Qiu JW. Palatability of macrophytes to the invasive freshwater snail Pomacea canaliculata: differential effects of multiple plant traits. Freshw Biol. 2010;55:2023-31.

Yahaya H, Nordin M, Hisham MNM, Mirudin H. Invasive apple snails in Malaysia. In: Joshi RC, Cowie RH, Sebastian LS, editors. Biology and management of invasive apple snails. Maligaya: Philippine Rice Research Institute (PhilRice); 2017. p. 169-95.

Yam RSW, Fan YT, Wang TT. Importance of macrophyte quality in determining life-history traits of the apple snails Pomacea canaliculata: implications for bottom-up management of an invasive herbivorous pest in constructed wetlands. Int J Environ Res Public Health. 2016;13:248.

Yan SW, Asmah R. Comparison of total phenolic contents and antioxidant activities of turmeric leaf, pandan leaf and torch ginger flower. Int Food Res J. 2010;17:417-23.

Yang TB, Wu ZD, Lun ZR. The apple snail Pomacea canaliculata, a novel vector of the rat lungworm, Angiostrongylus cantonensis: its introduction, spread and control in China. Hawaii J Med Public Health. 2013;72:23-25.

Yoshida K, Hoshikawa K, Wada T, Yusa Y. Life cycle of the apple snail Pomacea canaliculata (Caenogastropoda: Ampullariidae) inhabiting Japanese paddy fields. Appl Entomol Zool. 2009;44:465-74.

Yousif RA, Abdullah OJ, Ahmed AM, Adam MI, Mohamed Ahmed FA, Idam OA. Effect of replacing fishmeal with water spinach (Ipomoea aquatica) on growth, feed conversion and carcass composition for Nile tilapia fry (Oreochromis niloticus). J Aquat Sci Mar Biol. 2019;2:13-20.

Zedler JB, Kercher S. Causes and consequences of invasive plants in wetlands: opportunities, opportunists, and outcomes. Crit Rev Plant Sci. 2004;23:431-52. 